Joakim Byström / Dieter K. Müller, Umeå/Sweden

\title{
Tourism labor market impacts of national parks
}

\author{
The case of Swedish Lapland
}

\begin{abstract}
In a Nordic context, economic impacts of tourism in national parks remained largely unknown due to lacking implementation of standardized comparative measurements. For this reason, we want to investigate the economic impacts of national parks in a peripheral Scandinavian context by analyzing employment in tourism. Theoretically, the paper addresses the idea of nature protection as a tool for regional development. The scientific literature suggests that nature can be considered a commodity that can be used for the production of tourism experiences in peripheries. In this context nature protection is applied as a label for signifying attractive places for tourists leading to increased tourist numbers and employment. This argument follows mainly North American experiences pointing at a positive impact of protected areas on regional development. Meanwhile European studies are more skeptical regarding desired economic benefits. A major challenge is the assessment of tourism's economic impacts. This paper suggests an approach that reveals the impacts on the labor market. This is particularly applicable since data is readily available and, moreover from a public perspective, employment and tax incomes are of uppermost importance in order to sustain population figures and local demand for public services. At the same time accessibility and low visitor numbers form major challenges for tourism stakeholders and complicate the assessment of economic impacts through questionnaires and interviews. The paper shows that the assumption that nature protection promotes positive economic development through tourism is not applicable in a northern Swedish context. Hence, it rejects the often suggested positive relationship between nature protection and tourism labor market development.
\end{abstract}

Keywords: protected areas, national parks, economic impact, nature-based tourism, labor markets, peripheral areas

\section{Introduction}

The economic globalization and recent labor market restructuring of remote European regions has resulted in a new interest in tourism development (TownSEND, 1997; MüLLER/JANSSON 2007). The primary reason for this interest is the necessity of new job opportunities that can substitute for current losses in primary industries (MÜLLER/Ulrich 2007). Tourism development has been recognized as a means to stimulate the labor market and contribute to regional development in remote regions (HALL/JENKINS 1998; SHARPLEY 2002; HALl 2007) and is believed to provide a new beginning for economically vulnerable rural settings by increasing employment. Much of the tourism development in northern Sweden has been focusing on various forms of nature-based tourism due to the natural conditions of this remote region. In this context, not least national parks - which in Sweden usually belong to the IUCN II category ${ }^{1}$ - and other protected areas have been identified as important attractions capturing the relative pristine characteristics of the area.

However, evidence for the success of a tourismled strategy towards development is largely lacking. While it has been shown that tourism indeed increased its relative importance within the labor market, it is still unclear whether this is because of declining employment in other sectors or because of a real increase in tourism (MÜLLER/UlRICH 2007). Various stakeholders are interested in acquiring information on the regional economic impact of nature-based tourism and the possible contribution of national parks to increasing visitor numbers. In a Swedish context, the Swedish Environmental Protection Agency (SEPA), strategic planners and local entrepreneurs request hands-on statistics in regards to visitor numbers, jobs and flow of 
funds in order to justify investments in national parks or other recreation areas. Prior attempts to measure the economic impact of protected areas in the USA have often applied spending-related methods such as pure multiple analyses or the input-output analysis (STYNES et al. 2000). However, the methods and results of these studies cannot be applied in a Swedish context because the statistical basis is lacking, and on account of the more commercialized national park designs in the USA, making comparison difficult. Previous studies on the economy of national parks in northern Finland and central Sweden suggest that visitor spending can stimulate local economies and labor markets (HuHTALA 2007; FredMAN 2011). Moreover, studies from the UK indicate that nature-based tourism can contribute to economic development in peripheral areas (FInDLAY et al. 2000). Similar is reported from Germany (JoB et al. 2005; SCHMIDT 2006; WoLTERING 2011). Nevertheless, HALL (2007) argues that tourism often has failed to live up to these expectations. One example for this is Germany, where the question whether national parks are suitable tools for achieving sustainable development has recently been disputed (WEBER 2013). Here it was also shown that per diem expenditure by national park visitors is below the national average for tourists (MAYER et al. 2010). Moreover, even though the literature review indicates positive relationship between tourism to protected areas and local economy, the impact on employment remains unknown. The lack of knowledge can partly be explained by the fact that studies on protected areas are rather neglected within economic geography research even though such areas constitute a still growing land use on national and global scales (MAYER/ Jов 2014), a fact that also applies to Sweden.

The growing demand for tourists to experience wilderness has been based on the changed and more positive attitudes towards the environment in general (HALL/PAGE 1999), a development driven by new and evolving values (SAARINEN 2005). In addition, nature-based tourism is often perceived as the next wave contributing to regional development (JONSTON/PAYNE 2005). As a continuation of these arguments tourism itself can be developed in order to justify national parks (HALL/BOYD 2005).

The knowledge regarding the economy of protected areas is, however, affected by a lack of standardized comparative measurements. Even varying institutional and geographical settings influence the potential for economic development around national parks. The aim of this study is to identify the contribution of national parks to the local economy in gateway communities in northern Sweden by comparing labor market structures at these locations with the conditions in other gateway communities providing access to nature reserves. First, this paper presents previous findings related to the economic impacts of protected areas before moving on to the methodology and results of the study. Finally, the paper discusses the results with reference to the discourse on the relation of national parks to employment creation.

\section{The economy of protected areas}

The idea of protecting wilderness for developing tourism is not new and can be traced back to the first national parks in Europe where railway companies argued for establishing national parks close to the railway lines, which were constructed to harvest the natural resources of the North, in order to attract passengers (WALL ReINIUS 2009). Nevertheless, during the 20th century conservationist ideals became popular and supported the concept that national parks were created owing solely to their environmental qualities. However, the early 21 st century meant a rejuvenation of touristic motivations for the establishment of parks (Mose/WeIXLBAUMER 2007; JoB 2010; BECKEN/JoB 2014). This shift towards nature for people can be seen in the context of economic restructuring in many peripheral areas, where a decline in local and regional resource economies is offset with an emphasis on the relatively pristine nature. In order to create alternative economic values there has been a desire to commodify this pristine nature. Expected outcomes of such a process are regional growth and employment. In the Swedish case this change has been manifested through altered aims of the Swedish Environmental Protection Agency. As a result, the agency is now expected to protect for sustainable regional growth, which clearly aims at economic aspects far beyond and partly in conflict with the conservationist agenda (MÜLleR 2013).

Usually, economic impacts are composed of either direct, indirect or induced impacts (HALL/ LEw 2009). However, national tax systems may alter the share and importance of these types of impacts through redistribution. In Sweden, the tax system is designed such that individuals pay 
their tax to the municipality in which they have their permanent residence, while companies pay taxes at the national level. The Swedish Lapland has been suffering from depopulation during the last half century. This negative demographic development has come to be a serious problem for the tax base of the region. Further, seasonal employment creates an additional challenge since temporary workers can have their permanent residence elsewhere, resulting in tax-revenue leakage for the region. According to LUNDMARK (2006) as much as $25 \%$ of the workforce in the mountain regions of the Swedish Lapland are seasonal in-migrants not paying taxes in the municipality of work. The consequences of a reduced tax base include reduced funding for regional and local services, such as education and healthcare, along with reduced infrastructure investments. Hence, tax-revenue leakage can be considered a threat to regional development and municipal households. As a consequence of the tax system, the creation of local employment is at the center of regional development interests.

Hall/Page (1999) suggest that the growing demand for tourists to experience the wilderness has been based on the new and more positive attitudes towards the environment in general. SAARINEN (2005) argues that the wilderness takes on new values and meaning through social processes, while some of the previous ones could become remnants and as time passes become more distant for modern people. Today, it is likely that tourists' interests for touristic wilderness areas are shaping the modern perception of such areas. However, the touristic wilderness is constructed through direct and indirect tourism spending and is therefore based on consumption. Moreover, consumption requires commercial characteristics which then lead to employment and tourism development. Consequently, local nature-based tourism interests are depended on commercial success. According to Jonston/Payne (2005), nature-based tourism requires an untouched landscape that is physically accessible to tourism entrepreneurs in order to develop a tourism product within accepted parameters. However, this development is problematic in Swedish national parks due to restrictions towards commercial activities within these areas. Moreover though Sweden has altogether 29 national parks protecting an area of 730000 ha, the greatest in size as well as in appeal are located in the North far away from major population and demand centers (Fig. 1). Hence, the argument of increasing job opportunities as a direct result of
Fig. 1: National parks in Sweden

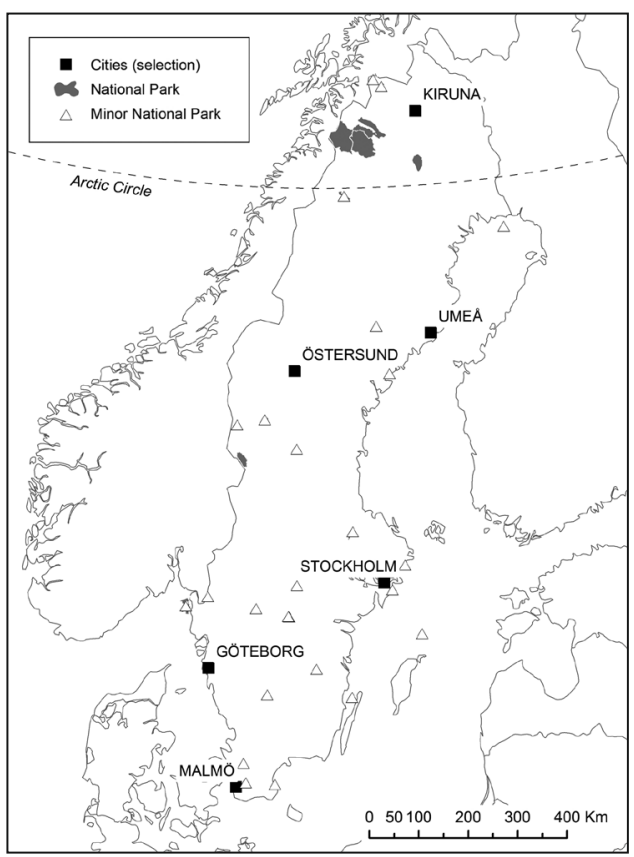

the establishment of a national park should be questioned.

Usually there are multiple stakeholders with diverse interests in a protected area setting (JAMAL/ STRONZA 2009) which together form a structure through their interactions and relations (HAUKELAND et al. 2011). Yet as mentioned previously, the possibility for commercial activities is limited in protected areas, and the more constrains there are the less freedom the various stakeholders have to conduct their commercial purposes (CAFFYn/JobBins 2009). Still, national parks have long been promoted as tourist destination in various places, including Sweden (SANDEL 2005; WALL REINIUS / FREDMAN 2007). In addition, the national park label is considered important in the promotion of tourism (WALL REINIUS / FREDMAN 2007; PALMER 1999) and is argued to have a significant brand identity which makes it more attractive than other protected area titles (EAGLES 2001). The national park product may very well be a more attractive brand than a nature reserve. For the German situation it was however shown that the role of the national park brand differs. In cases where national parks are located in already established destinations, their role for marketing was secondary; meanwhile they had a far greater 
role in peripheral and emerging destinations (HANNEMANN/Job 2003). Still national parks have been identified as important for regional development (JoB et al. 2005; SCHMIDT 2006; WOLTERING 2011; MAYER 2013).

In Sweden the national park label comes with stricter regulations in regards to commercial tourism, in comparison with a nature reserve. In the Vindelfjällen Nature Reserve, which will be further analyzed in this study, there are snowmobile services, helicopter tours and guided fishing trips within the nature reserve which are likely to contribute to the local economy. Such activities, which require permits, are not likely to be conducted in a national park setting due to restrictions, which may have a negative impact on the local economy, since nature-based tourism interests are depended on commercial success. Moreover, Swedish law allows for explorative mining within nature reserves, which previously has led to protests not among tourism entrepreneurs, but Sami reindeer herders and protectionists (MÜLLER 2013).

Much of what is perceived and promoted as wilderness in northern peripheral Sweden is associated with protected areas. National parks and nature reserves have mainly been established in remote settings with rural issues and challenges that can be related to labor market restructuring (Müller/Hall/Keen 2004; Müller/UlRICH 2007). The rural industries in Sweden have been increasingly marginalized over time which can be seen as a crisis for these areas that has resulted in depopulation, demographic issues and socio-economic insecurity (MÜLLER 2005). Nature-based tourism has often been promoted as a way to manage these structural changes, especially in remote areas (BAUM 1999; HALL/ BOYed 2005; Hall 2007). Still, there is no guarantee that tourism will live up to these expectations (HALL 2007). For example, LUNDMARK/ MÜLLER (2010) demonstrate the mismatch of demand and supply of nature-based tourism, where distance to demand markets is not mirrored in supply figures. Though rich in product supply, northern Sweden suffers from a low number of guest nights.

\section{Methodology}

In order to understand labor market impacts of protected areas and tourism development for this paper a case study was conducted. According to scholars, case studies are some of the most common approaches within tourism research and are considered a suitable strategy for exploring and explaining complex situations in a holistic manner (BEETON 2005; YIN 2003). Often studies of visitor expenditures are used to estimate the economic impact of protected areas (e.g. WOLTERING 2011; MAYER 2013). This requires however good conditions for data collection and good knowledge of annual visitor numbers. Both preconditions are not satisfied in the Swedish periphery, where the total number of visitors is usually low and spread out over the year. FREDMAN/YUAN (2011) try to overcome this problem by using registration boxes in the field for collecting addresses. The registered households are contacted later and asked to estimate their expenditures. However this procedure creates a time lag and was thus not considered an appropriate approach for this study, where focus is on labor markets and a longer time period.

In this case study, the impacts of protected areas on local economies are measured as impacts on the labor market, through a comparative analysis between gateway communities of national parks and nature reserves, respectively. The approach has been to analyze tourism employment in gateway communities with access to comparable natural conditions. To achieve this, data from a longitudinal geo-referenced database (ASTRID Umeå University) covering socio-economic information for all individuals in Sweden are used in a geographical information system (GIS) in order to assess the impact on the labor market. Geo-references for permanent residence and place of work are available on a $100 \mathrm{~m}$ grid, which enables detailed spatial analysis of the labor market.

To be able to analyze the development over time, several points in time had to be researched. However, it is central to identify possible economic fluctuations and other undesirable deviations to avoid non comparable years. By looking at commercial overnight stays in the study area over time, comparable time periods at five year intervals were identified which resulted in the following years: 1990, 1995, 2000, 2005 and 2010. The data has been organized by selecting individuals with a workplace in the study area. Based on Standard Industrial Classification Codes (SIC), employees and entrepreneurs in the tourism industry were further singled out within the study area. Tourism employment in this case is an individual's primary employment 
and includes accommodation (e.g. hotels, youth hostels, campsites), transportation (e.g. air traffic, busses) and other tourism services (e. g. skilifts, golf courses). As a result of this selection this study does not necessarily include all tourism impacts on the labor market as some occupations are be excluded. Retail for example is not included in the analysis, which is anyway not a major attraction in the context of national park tourism. Instead the analysis is limited to employment that clearly falls within what often is labeled the tourism industry. Moreover, economic impacts not resulting in local employment have not been measured in this study.

Through the data filtering and geo-referenced data, individuals working in tourism at six locations, categorized as gateway communities, around national parks and nature reserves, respectively, have been analyzed. The distinction between national parks and nature reserves has been made in order to identify eventual impacts of different protection status. Moreover, the gateway communities and environmental protection to which they have access to are comparable to each other since they offer the same or similar tourism products.

The level of tourism employment related to the protected areas has been analyzed through the use of impact or buffer zones centered on the workplace. There are two buffer zones considered in this study $(10 \mathrm{~km}$ and $50 \mathrm{~km})$ with the intention of identifying the impact of distance on tourism employment (Fig. 2). The absence of road links within the buffer zones is a problem which is explained by natural conditions such as mountains, rivers and lakes. To avoid various gateway communities (buffer zones) from influencing inaccessible settlements or workplaces, constraints related to the physical geography were included in the GIS model.

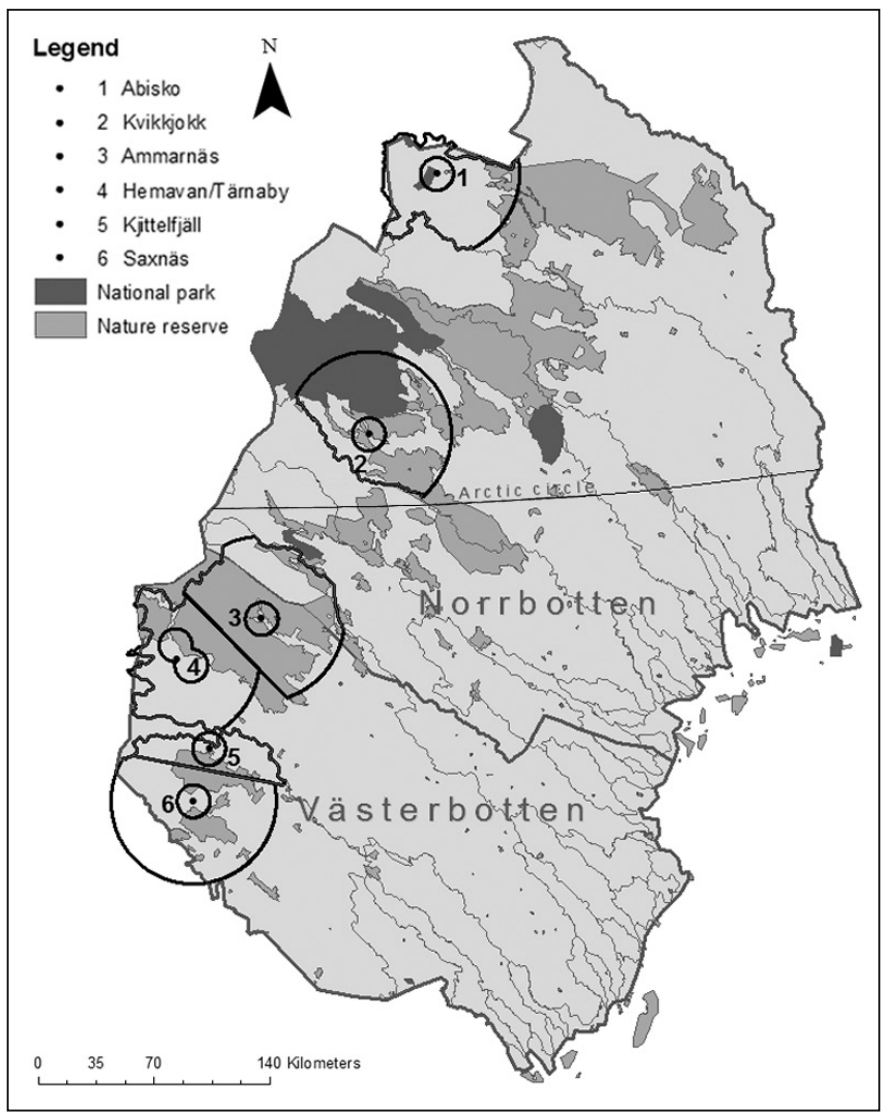

Fig. 2: Study area of northern Sweden with the buffer zones covering the gateway communities 
The gateway communities have been divided by river valleys, or basins, which otherwise could result in misleading employment statistics due to the possibility of individuals employed in tourism without any actual road link to the specific study areas. This was done by using GIS and adding a polygon between these basins, or other areas without any road links which still fall within the buffer zone radius. In addition, the permanent residences and places of work of tourism employees have been further analyzed to detect possible tax revenue leakage related to the tourism industry in northern peripheral Sweden. This has been done by analyzing tax revenues in relation to the gateway communities where the total number of tourism employees working in the buffer zones $(10 \mathrm{~km}$ and $50 \mathrm{~km})$ has been compared with the total numbers of permanent residents working within tourism.

There are limitations in the longitudinal georeferenced database. Individuals' workplaces are based on where people spend most working hours in any given year. As a consequence, shortterm seasonal employment in the tourism sector may be lost due to the individual having a longer employment elsewhere. Also, workplace can be registered as the location of payroll instead of where the employment actually takes place. It is difficult to say if and to what degree such limitations influence the results presented in relation to the various gateway communities in this study. It is, nonetheless, likely to have some effect since these limitations are associated with seasonal employment and labor hire-companies which dominate the tourism industry in northern peripheral Sweden. The results are therefore rather a conservative assessment of the employment impacts of tourism in this peripheral region than an exact representation of reality. However, it should be noted that the database is the source of information for all public statistics in Sweden and it has been used previously to assess restructuring in the tourism sector in Sweden (LuNDMARK 2005, 2006; LUNDMARK et al. 2010; MÜLLER 2013; MÜLLER/UlRICH 2007). Moreover, the study does not allow for assessing the impact of new establishments of protected areas. All protected areas in the region have been established for rather long time. In fact several of the included parks were established in 1909 already. Finally, as Fig. 2 indicates there are no villages in the mountain area that are not located nearby a protected area. Hence, comparisons with villages lacking access to protected areas are in fact impossible within the region.

\section{The geographical setting}

The study area covers the Swedish region of Lapland consisting of 12 municipalities situated in the interior of Sweden's two northernmost counties of Västerbotten and Norrbotten. The area is considered rural since it covers roughly a quarter of Sweden's total landmass but contains only around $4 \%$ of the total population. Furthermore, the study focuses upon the six gateway communities of Abisko, Kvikkjokk, Ammarnäs, Hemavan/Tärnaby, Kittelfjäll and Saxnäs. These areas have been selected since they are considered to offer the same or a similar tourism products. Still, there are important differences. The gateway communities of Hemavan/Tärnaby and Kittelfjäll are mainly ski resort destinations during the winter season with a greater commercial supply than the other gateway communities. Abisko also exhibits commercial characteristics due to the aurora borealis tourism, as well as skiing facilities within $50 \mathrm{~km}$. Kvikkjokk, Ammarnäs and Saxnäs, on the other hand, mainly offer recreational experiences such as hiking, fishing, hunting, cross-country skiing and snowmobile rentals. The variations in the characteristics of these destinations are categorized such that gateway communities with a protected area (focusing on landscape, nature and wilderness) as their primary attraction are considered park destinations, while gateway communities with another type of primary attraction (such as alpine skiing) are considered diversified destinations. Since all destinations are gateways to protected areas, environmental protection becomes a secondary attraction among those more diversified. The tourism industry in all selected places can be characterized as small-scale, seasonal and dominated by micro-firms. Only the providers of accommodation and alpine skiing facilities have greater numbers of employees. Still the seasonal characteristics of the industry imply that the workforce is not necessarily residing and registered in the community but elsewhere in Sweden and thus, the total share of tourism labor in the chosen communities is limited (Fig. 3). Furthermore, the workforce between the gateway communities varies greatly in size, which makes shares of employment statistics comparisons challenging to illustrate. As an example, four tourism employees in Kvikkjokk made up $100 \%$ of the total labor force in the region in 1990, but in Hemavan/Tärnaby, on the other hand, four tourism employees never made up more than $1 \%$ of the total labor force of the region at any given time. 
Fig. 3: Workforce at a $50 \mathrm{~km}$ zone surrounding the different gateway communities (combined total numbers for the years 1990, 1995, 2000, 2005, 2010)

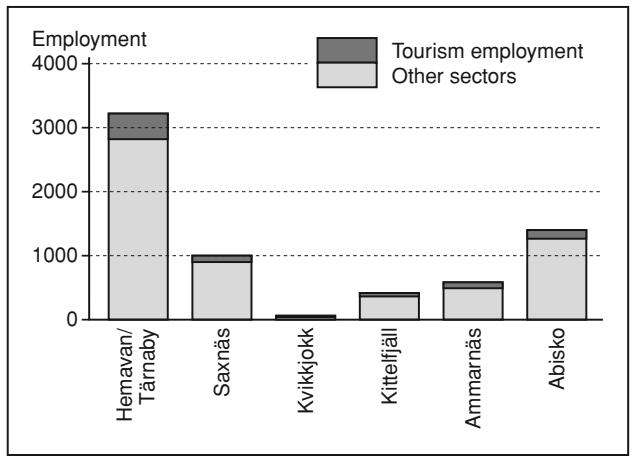

Source: ASTRID database

As a result, relative shares of tourism employment can be misleading when comparing smaller populations to other gateways. Nevertheless because of the many years and gateway communities, results are presented in relative numbers over time. Dramatic numbers related to small populations must therefore be understood with this background in mind.

\section{Results}

The $10 \mathrm{~km}$ and $50 \mathrm{~km}$ buffer zone analysis shows that there are labor market variations which can be related to the characteristics of the different gateway communities (Tab. 1). As expected, the diversified destinations have a relatively larger extent of tourism employment over time when analyzing the share of tourism employment to total employment. In addition, the more diversified destinations display a closer geographical proximity in terms of tourism employment concentration within the $10 \mathrm{~km}$ zone.

\section{$10 \mathrm{~km}$ catchment area}

Hemavan/Tärnaby and Kittelfjäll are ski resort destinations which makes the protected area to which they have access to a secondary attraction. Even though the mean value of tourism employment is larger at other gateway communities at certain times, these two destinations have a relatively large and steady level of tourism employment over time which never drops below $9.2 \%$ (Hemavan/Tärnaby 2010). Abisko is also considered a diversified destination since the national park to which it accesses is secondary to the nearby ski facility of Björkliden and aurora borealis tourism. Saxnäs, Ammarnäs and Kvikkjokk are all categorized as park destinations since their respective protected areas are their primary tourist attraction. These park destinations have a smaller proportion of tourism employment among the local residents, compared to the diversified destinations. However, when looking at the mean value on shares of tourism employment over time (Tab. 1), Kvikkjokk has the largest shares of tourism employment. This is explained by the relatively small workforce at this location, which still has a great impact on the share of employment even though the actual employed number is small.

\section{$50 \mathrm{~km}$ catchment area}

When expanding the buffer zone to $50 \mathrm{~km}$, the increase or decrease of share of tourism employment among local residents does not follow any given pattern. It is rather explained by a series

Tab. 1: Commercial characteristics of the gateway communities*

\begin{tabular}{lcccc}
$\begin{array}{l}\text { Gateway } \\
\text { community }\end{array}$ & $\begin{array}{c}\text { Commercial } \\
\text { characteristics }\end{array}$ & Primary attraction & $\begin{array}{c}\text { Average tourism em- } \\
\text { ployment } 10 \mathrm{~km}(\%)\end{array}$ & $\begin{array}{c}\text { Average tourism em- } \\
\text { ployment 50 } \mathrm{km}(\%)\end{array}$ \\
\hline Hemavan/Tärnaby & More commercial & Ski resort & 12.7 & 14.0 \\
Kittelfjäll & More commercial & Ski resort & 19.3 & 16.5 \\
Abisko & More commercial & Ski resort/aurora borealis & 8.0 & 12.7 \\
Saxnäs & Less commercial & Protected area & 7.2 & 12.8 \\
Ammarnäs & Less commercial & Protected area & 5.0 & 18.8 \\
Kvikkjokk & Less commercial & Protected area & 75.0 & 33.0 \\
\hline
\end{tabular}

* Average tourism employment's share (\%) of total employment based on individuals with a permanent resident within the $10 \mathrm{~km}$ and $50 \mathrm{~km}$ buffer zone (1990-2010). Tourism employment is presented in mean value of shares (\%) of total population. Source: own survey 
of factors such as increasing/decreasing tourism employment, changes in other sectors of the labor market and/or geographical diversification of tourism employment. The 1.3 increase in percentage points (pp) for the Hemavan/Tärnaby case is mainly explained by a significant share of employment outside the $10 \mathrm{~km}$ buffer zone in 1990 and 1995. However, the labor market progress in tourism has been developing towards a concentration within the $10 \mathrm{~km}$ buffer zone since that time. Looking at the 2010 data separately, only $8 \%$ of permanent residents employed in the tourism sector reside outside the $10 \mathrm{~km}$ zone, compared to $18 \%$ in 1990. Similar development is found in Kittelfjäll. The concentration of tourism employees within the $10 \mathrm{~km}$ buffer zone started earlier in the Kittelfjäll case, resulting in a decrease of $2.8 \mathrm{pp}$ when applying the $50 \mathrm{~km}$ zone. The 4.7 increase in $p p$ found in Abisko is explained by Riksgränsen, a ski facility located to the west of Abisko and within the $50 \mathrm{~km}$ zone. As a result, the ski resort becomes the primary attraction as the buffer zone expands.

The park destinations show a less stable labor market development both in terms of time and space. Dramatic labor market changes especially in Ammarnäs and Kvikkjokk are explained by the small workforce in combination with an absence of long-term commercial businesses. Saxnäs on the other hand, shows a relatively stable development within tourism employment since 1995. A huge drop in tourism's share of total employment between 1990 and 1995 is explained by growth in other sectors rather than a loss of actual jobs in tourism, when looking at total numbers.

\section{Diversified destinations}

The diversified destinations distinguish themselves by a relatively stable development in terms of tourism's share of total employment over time. This is likely to be the result of longterm commercial activities at these locations. The buffer zone analysis shows Hemavan/Tärnaby to have a large share of tourism employment as well as the steadiest number of employment over time, which varies between roughly 8 and $11 \%$ of the total employment. In addition, Hemavan/Tärnaby is the destination with the largest workforce in total numbers. Kittelfjäll shows a similar trend as Hemavan/Tärnaby in terms of mean value of tourism employment over time. However, Kittelfjäll has a greater variation from year to year, which is possibly related to the limited workforce at this destination. While most gateway communities have had their ups and downs, Abisko exhibits a steady increase of tourism employment. In 1990 the tourism sector accounted for $6 \%$ of the total employment, compared to $13 \%$ in 2010 . The main reason behind the increase in Abisko is its development as a summer destination to a year around destination, due to nearby ski facilities and the aurora borealis tourism. Over time, Hemavan/Tärnaby, Kittelfjäll and Abisko can be considered to be the most successful areas in terms of tourism employment.

\section{Park destinations}

Even though the mean value for tourism employment in Kvikkjokk and Ammarnäs seems rather large over time, it's only the result of sudden fluctuations based on other sectors of the labor market in combination with a small workforce. When looking at the $10 \mathrm{~km}$ zone over time, Ammarnäs has gone from approximately $3 \%$ tourism employment in 2000 to $0 \%$ in 2010, while Kvikkjokk has had $0 \%$ employment throughout the same period of time. Saxnäs has also had a negative development in terms of tourism employment with a $16 \mathrm{pp}$ decline in tourism employment since 1990 , ending up at $3.7 \%$ in 2010. The absence of long-term commercial establishments is likely to contribute to a shaky and somewhat unpredictable labor market development among the park destinations. As a result, it seems like the environmental protection itself is insufficient for a steady and positive development in tourism employment.

\section{Seasonal employment and tax revenue issues}

The geo-referenced employment data shows that a large share of tourism employees in the Swedish Lapland actually have their permanent residence (tax residence) elsewhere (Fig. 4). In $1990,16.5 \%$ of the tourism employees in the study area were found to have their permanent residence elsewhere. Even though the figure decreases over time and ends up at $9 \%$ in 2010 , this group of employees has a considerable economic impact at various places due to tax revenue matters.

To further analyze the tax revenue issue in relation to the gateway communities of this study, the total number of tourism employees with workplace in the buffer zones $(10 \mathrm{~km}$ and $50 \mathrm{~km})$ were compared with data of the total numbers of 
Fig. 4: Share of tourism employees in Lapland with permanent residence elsewhere (1990-2010).

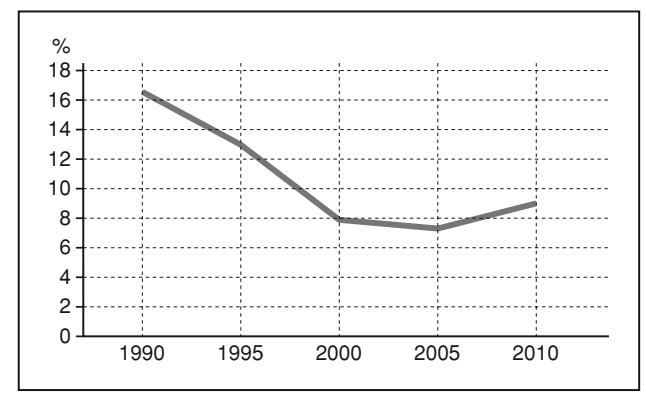

Source: ASTRID database

permanent residents working within tourism in the same geographical area. It turns out that the trend found in Lapland is not found at the gateway communities. On the contrary, it seems that some gateway communities (Hemavan/Tärnaby, Ammarnäs and Kvikkjokk) have more permanent residents working in tourism than tourism employees with a workplace in the area. This has been analyzed by studying (1.) overflow of individuals with a permanent residence working in tourism in relation to workplaces in tourism and (2.) overflow of workplaces in tourism (workplace) in relation to permanent residents working in tourism. A positive trend on workplace as the prevalent group could imply tax revenue leakage, since it's an indicator of individuals having their permanent residence elsewhere.

At both the $10 \mathrm{~km}$ and $50 \mathrm{~km}$ radius buffers, there is an overflow of permanent residents working in tourism in relation to workplaces in Hemavan/Tärnaby $(18 \%, 38 \%)$, Kvikkjokk $(100 \%, 57 \%)$, Ammarnäs (78\%, 51\%). Still, when looking at the $10 \mathrm{~km}$ zone, there are more workplaces in tourism than permanent residents working in tourism at Saxnäs (30\%), Kittelfjäll $(26 \%)$ and Abisko (19\%). This could suggest tax revenue leakage. However, regarding the $50 \mathrm{~km}$ zone there are more permanent residents working in tourism than there are workplaces in Saxnäs and Kittelfjäll, respectively, which indicates that there is a concentration of workplaces within the $10 \mathrm{~km}$ buffer zones at these locations at the same time as the individuals working in tourism tend to reside to a greater extent outside the $10 \mathrm{~km}$ radius. In Abisko, however, the overflow of workplaces increases from $19 \%$ to $39 \%$ as the buffer zone expands. This is also expected as the extended buffer now includes the ski facility of Riksgränsen. Based on the results, Abisko is the only gateway community that shows numbers pointing towards tax revenue leakage. This also indicates that the positive tourism development in Abisko is owing to the development of alpine skiing in Björkliden and Riksgränsen rather than due to the national park in Abisko.

\section{Discussion and analysis}

In a peripheral Swedish context, it seems that significant employment within tourism is made possible through commercial success. Commercial success, in turn, arises through the possession of winter season activities. This is mainly because tourist spending related behavior appears to differ depending on the season. During the summer, a lot of the tourism activities are related to hiking, camping and fishing; recreational activities that do not necessary contribute to any significant spending at the destination. During the winter season however, expenditures such as lift passes, overnight stays, snowmobile rentals and meals are made possible and therefore contribute to employment and regional development. This study shows that a lack of winter season activities results in less commercial characteristics and a reduced as well less stable tourism employment development. A further extension of this argument is that geographical proximity to a ski lift seems to contribute to tourism employment, which also has been shown in previous studies (LUNDMARK et al. 2010). The most central commercial characteristics seem to be: (1) possession of a winter season activity and (2) proximity to a ski lift, rather than access to a protected area. The label of the environmental protection (national park or nature reserve) appears to be of no major importance, instead, the commercial characteristics of the protected area appear to be important for regional development. A statistical analysis shows no correlation between national parks and tourism employment, or nature reserves and tourism employment. However, when looking at the most successful gateway communities in terms of tourism employment over time, it's obvious that commercial success is essential. Among the more diversified destination, Hemavan/Tärnaby and Kittelfjäll are access points to a nature reserve while Abisko is a gateway to a national park. In the Hemavan/Tärnaby and Kittelfjäll case, offpiste skiing, snowmobile tours and fishing are commercial activities occurring in the nature re- 
serves. However, the skiing facilities, which are the primary attraction, are located outside the protected areas. Abisko's primary attractions are the ski facilities within reach, both from a $10 \mathrm{~km}$ and $50 \mathrm{~km}$ perspective. Abisko National Park is a fairly small park from a northern Swedish perspective, which has contributed to the possibility of nearby skiing facilities. Also, the park is very accessible as both a major road and a railway line enter the park. Furthermore, the Aurora Sky Station promising spectacular views of the northern lights, is an attraction that has contributed to increasing visitor numbers. The Sky Station is located in the national park and is reached by a lift. The commercialization of Abisko National Park is unique in a Swedish context, and is likely to have contributed to the emergence of an active winter season, commercial success and positive employment growth in the tourism sector. Still, Abisko National Park is an unusual example since such interventions in national parks are rare due to the safeguarding of landscapes. It could be argued that Swedish national parks normally have clearer and stricter regulations in terms of interventions and commercial activities, compared to nature reserves. This means that it would be harder to develop commercial activities in national parks which in turn might have a negative effect on local labor markets.

The park destination of Kvikkjokk is a gateway to Sarek National Park which is often described as the most dramatic and scenic national park in northern Sweden. Still, Kvikkjokk has had a negative development in terms of tourism employment during the last two decades. This is likely because (1.) the national park is the only and primary attraction and (2.) the national park is difficult to access. In contrast to the Abisko National Park, there are no roads or railway lines leading to the Sarek National Park. Instead, Sarek is isolated and seems to be protected from human activity, rather than for human activity. Hall/Page (1999) argue that the development of more accessible natural areas has integrated peripheries with global and national tourism markets, which can be said to be the case in Abisko. This is an indicator suggesting that tourism can be an opportunity for these areas by turning some peripheral areas into more prosperous regions (GODDE et al. 2000), as long as they are accessible.

The park destination of Saxnäs borders the same nature reserve as Kittelfjäll without showing the same development in terms of tourism employ- ment. This is probably due to the absence of a ski facility. The same applies for Ammarnäs, which accesses the same nature reserve as Hemavan/ Tärnaby. Hence, it looks as if the protection status itself (national park/nature reserve) does not determine a destination's success. Instead, a more commercial primary attraction making the protected area secondary seems important for tourism employment. However, accessibility and permits for commercial activities (such as helicopter tours, snowmobile tours, sky centers etc.) help enhance the attractiveness of a protected area and by doing so at the same time enriching the secondary wilderness attraction.

Even though a significant tax revenue leakage is found in Swedish Lapland at a general scale, the same pattern could only be found at one of the gateway communities in this study. Still, it is possible that a leakage exists despite the fact that it can't be found in the current analysis. Employment agencies and other companies with a base elsewhere could disappear in the data due to the registration of payroll location instead of where the physical employment actually takes place, and could therefore contribute to misleading data. Moreover, individual workplaces are recorded based on where people spend most working hours in any given year. As a consequence, short-term seasonal employment in the tourism sector may be lost due to longer employments elsewhere. Previous studies have shown that as much as $14 \%$ of the tourism employees in the Swedish mountain range might have their permanent residence elsewhere (LUNDMARK 2006), which suggests that the statistical basis of this study could be improved.

\section{Conclusion}

This paper identifies two different groups among gateway communities: park destinations and diversified destinations. Park destinations are considered a less commercialized group since the protected areas which they access are their primary attraction. In addition, the park destinations are mainly summer destinations and exhibit a relatively unstable and poor development in terms of tourism employment. The diversified destinations, however, are year-round destinations with the winter season as their most lucrative time. In addition, the more commercial diversified destinations have a spatial proximity to ski facilities, which are considered their primary attraction, making the protected area secondary. 
Also, the diversified destinations have a larger share of tourism employment over time, as well as a more stable development. Of course, this has to be seen in the context of accessibility. Since alpine tourism often generates greater of visitor numbers, investment into improved accessibility are more likely and do thus further contribute to growth and spatial concentration of tourism.

The label of nature protection (national park or nature reserve) seems to be of less importance for tourism employment than (1.) possession of an active winter season and (2.) proximity to a ski facility. However, the type of conservation can be of importance since the labor market effects for commercial activities in protected areas are related to regulations and permits. As a result, environmental protection as a secondary attraction provides greater positive impacts on local labor markets if regulations concerning commercial activities are more relaxed. An extension of this suggestion proposes that nature reserves generally can be considered to contribute to more positive effects on local labor markets, since national parks normally involve stricter regulations in terms of interventions and commercial activities.

\section{Acknowledgment}

The research presented in this paper was prepared within the projects MISTRA Arctic Futures and MISTRA Arctic Sustainable Development, both financed by MISTRA, the Swedish Foundation for Strategic Environmental Research.

\section{Note}

1 IUCN (International Union for Conservation of Nature) category II of protected areas covers large natural or near natural areas set aside to protect large-scale ecological processes, along with the complement of species and ecosystems characteristic of the area, which also provide a foundation for environmentally and culturally compatible, spiritual, scientific, educational, recreational, and visitor opportunities (http://www.iucn.org).

\section{References}

BAuM, T. (1999): Themes and issues in comparative destination research. The use of lesson-drawing in comparative tourism research in the North Atlantic. In: Tourism Management, (20)5, 627-633.

BeCKEN, S. / JoB, H. (2014): Protected areas and sustainable tourism planning. Preparing for global-local challenges. In: Journal of Sustainable Tourism (forthcoming).
BeEton, S. (2005): The case study in tourism research. A multi-method case study approach. In Ritchie, B. W. / Burns, P. M. / Palmer, C. (Eds.): Tourism research methods. Integrating theory with practice. Wallingford, 37-48.

CAFFyn, A. / JobBins, G. (2009): Governance capacity and stakeholder interactions in the development and management of coastal tourism. Examples from Morocco and Tunisia. In: Journal of Sustainable Tourism, (11)2-3, 224-245.

EAGLES, P. F. J. (2001): International trends in park tourism. Matrei, Austria (EUROPARC 2001, October 3-7, 2001, Hohe Tauern National Park, conference paper).

Findlay, A. / Short, D. / Stockdale, A. (2000): The repopulation of rural Scotland. Opportunity and threat. In: Journal of Rural Studies, (16)2, 243-257.

Fredman. P./Yuan, M. (2011): Primary economic impacts at three spatial levels. The case of Fulufjället National Park, Sweden. In: Scandinavian Journal of Hospitality and Tourism, (11)1, 74-86.

Hall, C.M. (2007): North-south perspectives on tourism, regional development and peripheral areas. In: Müller, D. K. / Jansson, B. (Eds.): Tourism in Peripheries: Perspectives from the far North and South. Wallingford, 19-37.

Hall, C.M./Boyd, S. (2005): Nature-based tourism in peripheral areas: Introduction. In: Hall, C.M./Boyd, S. (Eds.): Nature-based tourism in peripheral areas. Development or disaster? Clevedon, 3-17.

Hall, C.M./LEw, A.A. (2009): Tourism and its sociocultural impacts. In: Hall, C.M./Lew, A.A. (Eds.): Understanding and managing tourism impacts: An integrated approach. London, 141-185.

Hall, C. M. / PAGE, S.J. (1999): Introduction: Tourism Matters. In: Hall, C. M. / Page, S. J. (Eds.): The Geography of tourism. Environment, place and space. London/New York, 1-22.

Hall, C. M./ Jenkins, J. M. (1998): The policy dimensions of rural tourism and recreation. In: Butler, R./ Hall, C. M./ Jenkins, J. (Eds.): Tourism and recreation in rural areas. Chichester, 19-42.

Hannemann, T./Job, H. (2003): Destination „Deutsche Nationalparke" als touristische Marke. In: Tourism Review, (58)2, 6-17.

Huhtala, M. (2007): Assessment of the local economic impacts of national park tourism. The case of PallasOunastunturi National Park. In: Forest Snow and Landscape Research, (81)1, 223-238.

Haukeland, J.V. / Daugstad, K. / Vistad, O. I. (2011): Harmony or conflict? A focus group study on traditional use and tourism development in and around Rondane and Jotunheimen National Parks in Norway. In: Scandinavian Journal of Hospitality and Tourism, (11)1, 13-37.

JAmal, T. / StronZA, A. (2009): Collaboration theory and tourism practice in protected areas: Stakeholders, structuring and sustainability. In: Journal of Sustainable Tourism, (17)2, 169-189

JoB, H. (2010): Welche Nationalparke braucht Deutschland? In: Raumforschung und Raumordnung, (68)2, 75-89.

Job, H. / Harrer, B. / MetZler, D. / HajizAdeh-Alamdary, D. (2005): Ökonomische Effekte von Großschutzgebieten. Untersuchung der Bedeutung von Großschutzgebieten für 
den Tourismus und die wirtschaftliche Entwicklung der Region. Bonn-Bad Godesberg. (Bundesamt für Naturschutz).

Johnston, M. / PAYNE, R. (2005): Ecotourism and regional transformation in Northwestern Ontario. In: Hall, C.M. / Boyd, S. (Eds.): Nature-based Tourism in Peripheral Areas: Development or Disaster? Clevedon, 21-35.

LUNDMARK, L. (2005): Economic restructuring into tourism in the Swedish mountain range. In: Scandinavian Journal of Hospitality and Tourism, (5)1, 23-45.

LUNDMARK, L. (2006): Mobility, migration and seasonal tourism employment. Evidence from Swedish mountain municipalities. In: Scandinavian Journal of Hospitality and Tourism, (6)3, 197-213.

Lundmark, L. J. / Fredman, P. / SANDELL, K. (2010): National parks and protected areas and the role for employment in tourism and forest sectors: a Swedish case. In: Ecology and Society, (15)1, 190-209.

LundMark, L. / Müller, D. K. (2010): The supply of nature-based tourism activities in Sweden. In: Tourism, (58)4, 379-393.

MAYer, M. (2013): Kosten und Nutzen des Nationalparks Bayerischer Wald. Eine ökonomische Bewertung unter Berücksichtigung von Tourismus und Forstwirtschaft. München.

MAYER, M./Job, H. (2014): The economics of protected areas - a European perspective. In: Zeitschrift für Wirtschaftsgeographie, (58)2-3, 73-97.

Mayer, M. / Müller, M. / Woltering, M. /Arnegger, J./ JoB, H. (2010): The economic impact of tourism in six German national parks. In: Landscape and Urban Planning, (97)2, 73-82.

Mose, I. / Weixlbaumer, N. (2007): A new paradigm for protected areas in Europe? In: Mose, I. (Ed.): Protected areas and regional development in Europe. Towards a new model for the 21st century. Aldershot, 3-20.

MüLLER, D. K. (2005): Second home tourism in the Swedish mountain range. In Hall, C.M. / Boyd S. (Eds.): Naturebased tourism in peripheral areas. Development or disaster? Clevedon, 133-148.

Müller, D. K. / Hall, C. M. / KeEn, D. (2004): Second home tourism impact, planning and management. In Hall, C.M./ Müller, D. K. (Eds.): Tourism, Mobility and Second Homes: Between Elite Landscape and Common Ground. Clevedon, 15-32.

MüLLER, D. K. (2013): Hibernating economic decline? Tourism and labor market change in Europe's northern periphery. In: Visser, G. / Ferreira, S. (Eds.): Tourism and Crisis. London, 113-128.
MüLleR, D. K. / UllRich, P. (2007): Tourism development and the rural labour market in Sweden, 1960-1999. In: Müller, D. K. / Jansson, B. (Eds.): Tourism in Peripheries: Perspectives from the Far North and South. Wallingford, 85-108.

PAlmer, C. (1999): Tourism and the symbols of identity. In: Tourism Management, (20)1, 313-321.

SAARINEN, J. (2005): Tourism in the northern wildernesses. Wilderness discourses and the development of nature-based tourism in Northern Finland. In: Hall, C.M./Boyd, S. (Eds.): Nature-based Tourism in Peripheral Areas: Development or disaster? Clevedon, 36-49.

SAndell, K. (2005): Access, tourism, and democracy. A conceptual framework and the non-establishment of a proposed national park in Sweden. In: Scandinavian Journal of Hospitality and Tourism, (5)1, 63-75.

ScHMIDT, J. (2006): Regionalökonomische Wirkungen von Großschutzgebieten. Eine empirische Studie zu den Nationalparken in Deutschland. Hamburg.

Stynes, D. J. / Propst, D. B. / Chang, W. / Sun, Y. (2000): Estimating national park visitor spending and economic impacts. The MGM2 model. Final report to National Park Service. East Lansing, Michigan. (Department of Park, Recreation and Tourism Resources, Michigan State University).

Townsend, A. R. (1997): Restructuring, flexibility and unemployment. In: Townsend, A. R. (Ed.): Making a Living in Europe: Human Geographies of Economic Change. London, 2-49.

Wall Reinius, S. (2009): A ticket to national parks? Tourism, railways, and the establishment of national parks in Sweden. In: Frost, W. / Hall, C. M. (Eds.): Tourism and National Parks: International Perspectives on Development, Histories and Change. London, 184-196.

Wall Reinius, S. / Fredman, P. (2007): Protected areas as attractions. In: Annals of Tourism Research, (34)4, 839-854.

WEBER, F. (2013): Naturparke als Manager einer nachhaltigen Regionalentwicklung: Probleme, Potenziale und Lösungsansätze. Wiesbaden.

Woltering, M. (2012): Tourismus und Regionalentwicklung in deutschen Nationalparken. Regionalwirtschaftliche Wirkungsanalyse des Tourismus als Schwerpunkt eines sozioökonomischen Monitoringsystems. Würzburg.

YIN, R. K. (2003). Introduction: How to know whether and when to use case studies as a research method. In: Yin, R. K. (Ed.): Case study research: Design and Methods. London, 3-21. 